\title{
7. Student Loan Reform in China: Problems and challenges
}

\author{
Wei Jianguo and Wang Rong \\ China Institute for Educational Finance Research, \\ Peking University
}

\section{Development of Student Loans in China}

The development of student loans in China accompanies China's higher education 'massification'. In 1999, the Chinese government launched a policy onhigher education expansion. Since then, Chinese higher education has shifted rapidly from elite education to mass education. In 2002, China's gross enrolment rate in higher education increased to 15 per cent from 9.8 per cent in 1998 -meeting the minimum standards of mass higher education defined by Professor Martin Trow. The rate increased to 23 per cent in 2007. In the process of promoting mass higher education, the Chinese government has also reformed the previous free tuition policies. Starting in 1997, all students who are enrolled at public higher education institutions (HEIs) are required to pay for tuition. According to the latest statistics, revenue from tuition and fees in 2007 accounted for 33.66 per cent of the total expenditure of Chinese ordinary HEIs (Ministry of Education 2008:28). The introduction of these macro-policies brought about a real problem: how to help the growing number of needy students to successfully complete their higher education.

Many countries have adopted student loan schemes to share the cost of higher education. To resolve the above-mentioned problem, China has also launched a student loan policy. ${ }^{1}$ So far, four patterns of student loan programs have developed in China: commercial bank loans from an agency in the HEI's region; ${ }^{2}$

\footnotetext{
1 In addition to student loans, financial assistance to Chinese students includes: grants, national incentive scholarships, work-study programs, tuition waivers and reductions, subsidies for needy students, 'one-stop student assistance stations for financially needy students', and so on.

2 The student loans originated by commercial banks - that is, state-subsidised student loans, which will be mentioned below.
} 
rural credit cooperative ${ }^{3}$ loans from an agency in the household's region; a China Development Bank ${ }^{4}$ loan from an agency in the HEI's region; and a China Development Bank loan from an agency in household's region. ${ }^{5}$

In 1999, state-subsidised student loans were experimented with in HEIs controlled by the relevant ministries of the State Council in eight pilot cities, and the Industrial and Commercial Bank of China (ICBC) was the bank that handled the matter. In 2000, the program expanded across the country, and its administering bank expanded from the ICBC to also include the Agricultural Bank of China, the Bank of China and the China Construction Bank. ${ }^{6}$

When the state-subsidised student loan program was implemented nationally, some provinces startedinstitutional innovations in student loans. In July 2001, Zhejiang Province launched a Rural Credit Cooperative loan from an agency in the household region, which was the first in China. At present, this pattern of student loans is carried out in many other areas.

In 2003, the origination of state-subsidised student loans encountered obstacles. As the program has the features of large quantities, high cost and high risk, commercial banks do not want to get involved. The provision of state-subsidised student loans stopped in nearly all parts of the country. In order to promote state-subsidised student loans, the Ministry of Education, the Ministry of Finance, the People's Bank of China and the China Banking Regulatory Commission jointly issued 'Several Opinions on Further Improving the Work on the State-Subsidised Students Loans' in June 2004-reforming previous policies of the program. During the same period, the China Development Bank distributed student loans in some provinces. This program originated in Henan Province, so it is also known as the 'Henan Pattern'. After the adjustment of the state-subsidised student loan policies in 2004, student loans in Henan have not been provided completely. In December 2004, the country's only pilot province, Henan, cooperated with the China Development Bank (Henan Branch) in student loan business. Afterwards Qinghai Province followed suit. At present, that pattern has also been adopted in Shanxi, Hunan, Guangdong, Inner Mongolia, and other places.

3 Rural credit cooperatives are rural financial institutions providing financial services for their members. They are set up with the approval of the People's Bank of China. Their shares come from their members and therefore are under democratic administration. At present, rural credit cooperatives are undergoing reform and some have shifted to become rural cooperative banks.

4 The China Development Bank is different from the commercial banks mentioned previously. It was established in 1994 and is a policy financial institution controlled directly by the State Council. Its funds come mainly from the domestic and foreign bond markets. At present, reform of the China Development Bank is also under way.

5 The HEI's region refers to the location of the HEI at which the student studies; the household region refers to the place where the home of the student is located.

6 These banks are operated in accordance with the Law of the People's Republic of China on Commercial Banks. 
In 2007, the State Council issued the 'Opinions on Establishing and Improving the Policies for Subsidising Students in Universities of Regular Undergraduate Education, Post-Secondary Vocational Schools and Secondary Vocational Schools from Families with Financial Difficulties', making a major adjustment to the student-assistance system, which is also the biggest step since the higher education expansion. The document also suggested the China Development Bank loan from an agency in the household region and experimented with this in Jiangsu, Hubei, Chongqing, Shaanxi and Gansu.

\section{Comparison of Four Patterns of Student Loan Programs in China}

Below we provide a comparison of China's four types of student loan programs from aspects of the principal provider, the borrower's eligibility, loan size, loan origination, interest subsidy, risk-sharing, repayment conditions, loan collection, and so on (see Table 7.1 for a summary).

\section{Principal Provider}

The principal of the current four types of Chinese student loans is provided by financial institutions and not directly by the government. The principal of the commercial bank loan from an agency in the HEI's region is provided by the commercial banks in the HEI's region. The principal of the rural credit cooperative loan from an agency in the household region is provided by the rural credit cooperatives in the student's household region.

\section{Borrower's Eligibility}

The borrowers of a commercial bank loan from an agency in the HEI's region should be full-time junior-college students, undergraduate students, second bachelor'sdegree students or graduate students from public ordinary colleges and universities. For a rural credit cooperative loan from an agency in the household region, it is more complicated. In some provinces, the students themselves apply for loans, but in others, parents apply instead; in some areas, loans are not granted to students in private HEIs and independent colleges, ${ }^{7}$ and in others they are accessible to all; some loans are given to second bachelor's degree students and graduate students, but other loans are given

7 Independent college results from China's higher education reform; they are set up by ordinary universities under the new mechanism and models. They are not public institutions of higher education. Enterprises, institutions, social groups or individuals may serve as partners and provide the necessary conditions and facilities for operating the colleges and participating in their management and supervision. The colleges independently enrol, grant certificates and conduct financial accounting. They have legal personality and bear civil liability. 
only to ordinary junior-college students and undergraduate students. For the China Development Bank loan from an agency in the HEI's region, eligible borrowers are similar to those in the commercial bank loan from an agency in the HEI's region. For the China Development Bank loan from an agency in the household region, it is required that the borrowers be ordinary junior-college students or undergraduate students, excluding postgraduates and second bachelor's degree students. It is also required that students and their parents sign the loan contracts as co-borrowers. In addition, students in private HEIs and independent colleges may apply for the China Development Bank loan from an agency in the HEI's and the household's regions. Apart from the above requirements, applicants for all four types of student loans must be students from families with financial difficulties.

\section{Loan Size}

The loan size of all four patterns of student loan is generally limited to no more than RMB6000 each year.

\section{Loan Origination}

The originations of the four student loan patternsvary greatly. Under the commercial bank loan from an agency in the HEI's region, the loan origination is completed by HEIs and commercial banks. Under rural credit cooperative loans from an agency in the household's region, the rural credit cooperatives originate the loans themselves. For the China Development Bank loan from an agency in the HEI's region, HEIs are mainly responsible for loan origination. For the China Development Bank loan from an agency in the household's region, all counties or districtsin pilot provinces have been required to set up student-assistance management centres in charge of the loan's origination.

\section{Interest Subsidy}

It is the government that will subsidise the interest of all four patterns when the students are in school. Under a commercial bank loan from an agency in the HEI's region, the loan's interest is centrally controlled by the HEIs but is borne by the central government, and that of students in locally owned HEIs is borne by the local government. For rural credit cooperative loans from an agency in the household's region, the interest is borne by the provincial government sometimes, but otherwise is borne by the corresponding local government according to the affiliation of the HEIs. For the China Development Bank loan from an agency in the HEI's region, the interest is generally borne by the corresponding local government. For the China Development Bank loan 
from an agency in the household's region, the level of government that will bear the interest is determined by the affiliation and location of the HEI the student is enrolled in.

\section{Risk-Sharing}

A risk compensation fund is generally established to share risk in China's student loans. The system was introduced during the reform in 2004. The amount of risk compensation is equal to the loan amount multiplied by the ratio of the risk compensation fund. Under commercial bank loans from an agency in the HEI's region, the HEI and the government that the HEI is affiliated with each bears half of the risk compensation fund. The ratio of the risk compensation fund is determined when banks bid for the final selection of the administration of the student loan. It is more complicated for risk compensation funds in a rural credit cooperative loan from an agency in the household's region. ${ }^{8}$ For example, the HEI and the local government each bears half in some provinces, but in others, the local government shouldersthe whole amount. For the China Development Bank loan from an agency in the HEI's region, the ratio is determined when negotiation between the provincial student assistance centre and the provincial branch of the China Development Bank is carried out and it is shared equally by the provincial government and the HEI. For the China Development Bank loan from an agency in the household's region, the ratio of risk compensation is 15 per cent, according to the policies governing pilot areas. Which level of government will bear the risk compensation fund is determined by the affiliation and location of the HEI the student is enrolled in.

\section{Repayment Conditions}

The interest on the loan incurred from the date of the student's graduation is paid by the student (or their parents). Under the commercial bank loan from an agency in the HEI's region, students may choose to repay the principal within one-two years after their graduation according to their employment and income. The principal and interest must be paid off within six years after graduation. ${ }^{9}$ Under the rural credit cooperative loan from an agency in the household's region and the China Development Bank loan from an agency in the HEI's region, the principal and interest also must be paid off within six years after graduation. The loan-repayment term of the China Development Bank loan from an agency in the household's region is

8 In this type of student loan, in some provinces borrowers are also required to provide a guarantee.

9 The students who signed their loan contract before the reform in 2004 must pay off the principal and interest within four years after graduation. 
determined in accordance with the full-time study period of junior college or university with an addition of 10-year limits, reaching a maximum of 14 years. The grace period is the time while students are studying at the HEI and two years after graduation. After that period, students and their parents must repay the principal in yearly instalments in accordance with their loan contracts. An undergraduate must pay off all the principal and interest within eight years after the grace period. In terms of the repayment mode, for both the China Development Bank and the rural credit cooperative loan from an agency in the household's region, in some provinces this is paid yearly, while the principal and interest of the commercial bank loan from an agency in the HEI's region may be paid by yearly, quarterly or monthly. All loans may be repaid ahead of schedule. Borrowers need to pay the actual interest only. Under the commercial bank loan from an agency in the HEI's region and the China Development Bank loan from an agency in the HEI's region, if a student borrower continues their postgraduate study, the banks will provide him with a loan-repayment extension. The government subsidises the interest at the corresponding level. In addition, if graduates from centrally controlled HEIs work in the grassroots units in the western regions or remote areas for three or more years, the central government will repay the loan's principal they receive in school and the interest incurred previously. Such a system has also been implemented in some provinces so that when graduates of provincially owned HEIs work in designated places, the provincial government will pay the principal and interest of student loans.

\section{Loan Collection}

Different loan types vary in their method of collection. Under the commercial bank loan from an agency in the HEI's region, HEIs and banks are responsible for collection. ${ }^{10}$ Under the rural credit cooperative loan from an agency in the household's region, rural credit cooperatives themselves are responsible for collection. Under the China Development Bank loan from an agency in the HEI's region, HEIs are responsible for the collection. The final settlement of the risk compensation fund links to the HEIs' loan-collection performance. If the loans are collected well and the loan default amount is less than the risk compensation fund then the HEIs will be able to receive the remainder as rewards. Under the China Development Bank loan from an agency in the household's region, the student assistance centre at the county level is responsible for the loan recovery. If the loans are collected well, the student assistance centre at the county level is also correspondingly rewarded by the risk compensation fund as an incentive.

10 As the commercial banks are reluctant to offer student loans, generally, HEIs are responsible for loan collection in practice, so as to motivate commercial banks. 


\begin{tabular}{|c|c|c|c|c|c|c|c|c|c|}
\hline & 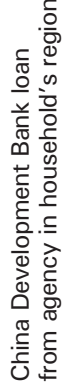 & 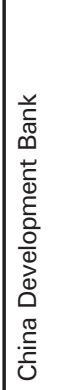 & 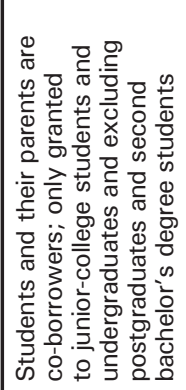 & 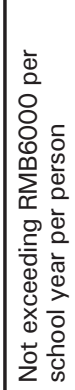 & 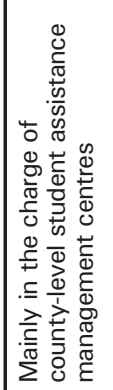 & 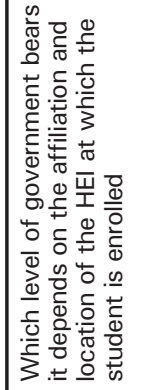 & 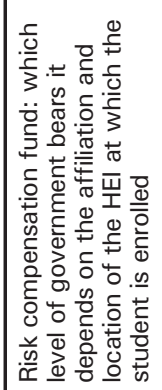 & 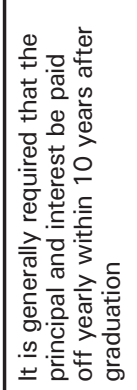 & 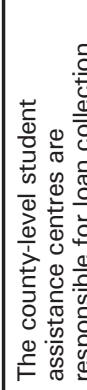 \\
\hline & 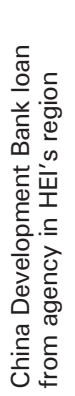 & 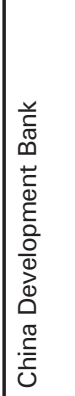 & 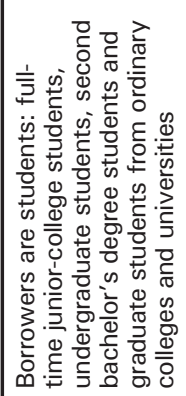 & 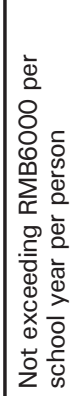 & 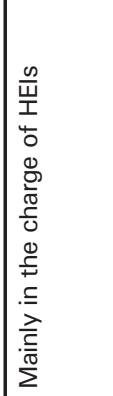 & 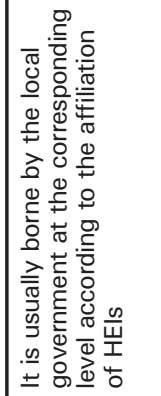 & 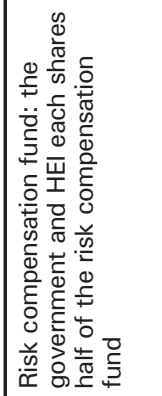 & 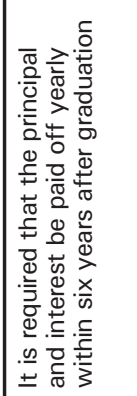 & 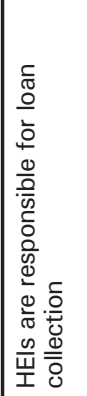 \\
\hline & 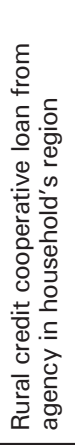 & 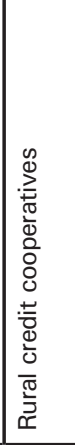 & 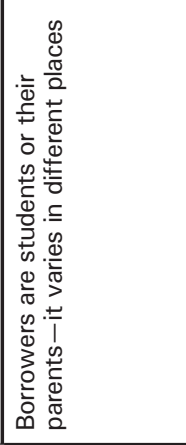 & 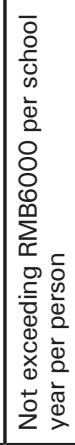 & 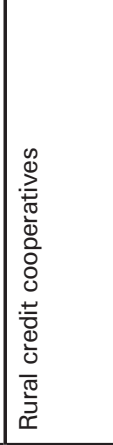 & 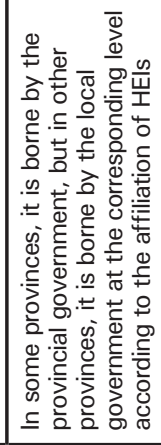 & 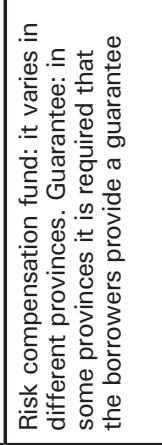 & 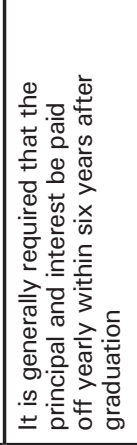 & 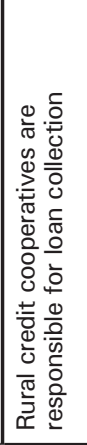 \\
\hline & 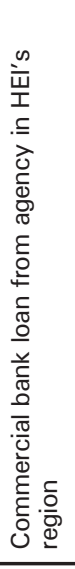 & 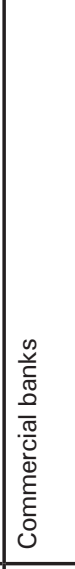 & 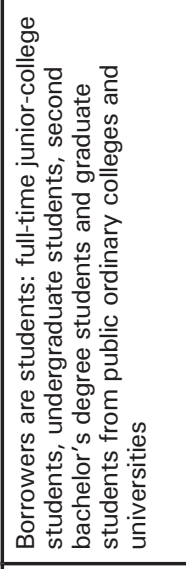 & 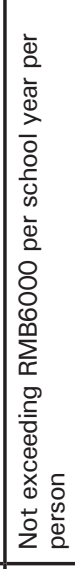 & 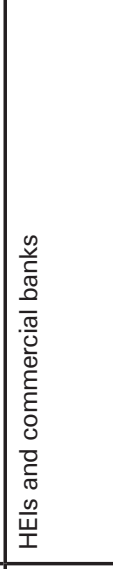 & 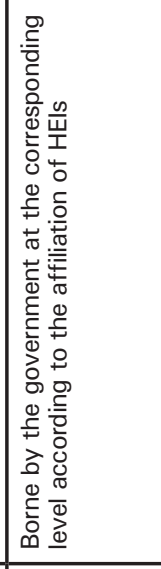 & 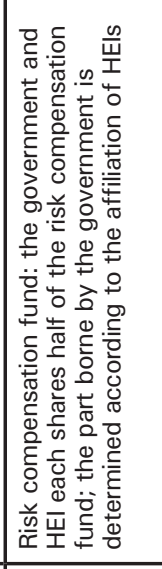 & 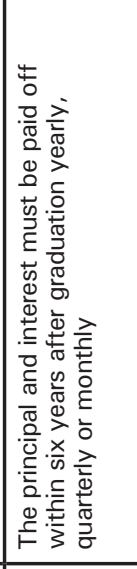 & 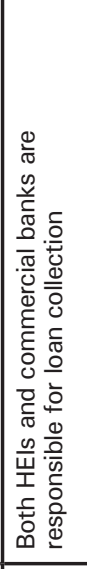 \\
\hline & & 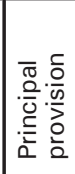 & 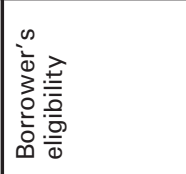 & 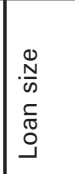 & 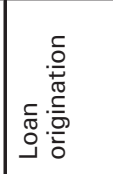 & 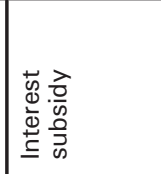 & 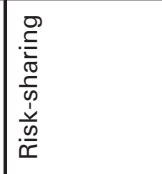 & 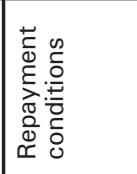 & 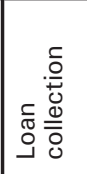 \\
\hline
\end{tabular}




\section{Problems and Challenges Confronting Chinese Student Loan Reform}

The four types of student loans play an important role in helping needy students successfully complete their studies. It is noteworthy that none of the current four types is perfect. At the national level, as an important part of the studentassistance system, student loans have not yet functioned to their full extent. The development of Chinese student loansis facing many problems and challenges.

1. Some students are not yet eligible to apply for student loans. There are restrictions on the eligibility of applicants from private HEIs and independent colleges. Some loans are not accessible to graduate students.

2. The loan size fails to meet the needs of some students. At present, the maximum amount of all loan types is RMB6000 per annum. According to the study of Song Yingquan, however, the private educational expenditure of a student in a locally owned HEI, on average, is more than RMB10 000 (Yingquan n.d.), including tuition and fees, accommodation, board expenses, and transportation fees. In addition, the tuition fees for medicine and art majors are higher than for other majors. Generally, the tuition fees of private HEIs and independent colleges are more than RMB10 000. As a result, for students with nogrant or other form of financial assistance, the current loan size is not enough to pay for their higher education costs.

3. The distribution of student loans cannot fully meet the needs of the students. According unpublished data from the Ministry of Education, ${ }^{11}$ since the adjustment of student loan policies in 2004 (see Table 7.2), there is still a wide gap between the number of students receiving student loans and the number of applicants. In addition, according to a survey we conducted in 2007, ${ }^{12}$ the success rate of applications for loans is not high. Of the 8120 students in the sample survey, a total of 1434 applied for student loans, accounting for 18.54 per cent of valid samples; 6312 did not apply; and 374 students did not provide any information. Of the 1434 students who applied for student loans, only 961 eventually received a loan. The success rate of applications for student loans is 67.02 per cent. These data show that the loan requirements for students from families with financial difficulties have not been met.

11 The summary data include data for all types of student loans.

12 The survey was conducted in 30 HEIs in Zhejiang, Jiangsu, Hubei, Sichuan, Qinghai and Ningxia provinces and autonomous regions. A total of 8152 student questionnaires were handed out and 8120 valid, completed questionnaires were returned. 
Table 7.2 Statistics of distribution of student loans nationwide, 2004-06

\begin{tabular}{l|c|c|c}
\hline & $\mathbf{2 0 0 4}$ & $\mathbf{2 0 0 5}$ & $\mathbf{2 0 0 6}$ \\
\hline $\begin{array}{l}\text { The total number of on-campus } \\
\text { students (10 000 people) }\end{array}$ & 1350 & 1387 & 1849 \\
\hline $\begin{array}{l}\text { The number of loan applicants } \\
\text { (10 000 people) }\end{array}$ & 70.32 & 118.31 & 190.00 \\
\hline $\begin{array}{l}\text { The number of students receiving } \\
\text { loans (10 000 people) }\end{array}$ & 36.73 & 91.61 & 85.50 \\
\hline $\begin{array}{l}\text { The success rate of loan } \\
\text { applications }\end{array}$ & $52.23 \%$ & $77.43 \%$ & $44.74 \%$ \\
\hline
\end{tabular}

Source: Ministry of Education, unpublished data.

4. The student loan coverage varies in different colleges and universities. The coverage in centrally controlled HEIs is higher than in locally owned HEIs. In 2004, the student loan coverage of HEIs controlled by the Ministry of Education, those controlled by other ministries and locally owned HEIs was 9.04 per cent, 7.13 per cent and 1.60 per cent, respectively. In 2005, the corresponding coverage was 7.11 per cent, 7.55 per cent and 6.50 per cent (see Tables 7.3 and 7.4). In addition, the situation in locally owned vocational colleges is not as good as in regular undergraduate colleges and universities. According to a survey carried out in 2007, we can see the differences of coverage between locally owned regular undergraduate colleges and universities and vocational colleges. In locally owned regular undergraduate colleges and universities, 391 of the 2349 students in our sample survey received student loans - accounting for 18.55 per cent. In the case of locally owned vocational colleges, 459 of the 4213 students in our sample survey received student loans-accounting for 12.16 per cent. In addition, there are no considerable differences between the tuition fees of vocational colleges and regular undergraduate colleges and universities. Moreover, the family economic situations of students in vocational colleges are even worse (Yingquan n.d.). These factors make it more difficult for vocational-college students to pay for higher education. In addition, compared with students in public HEIs, students from private HEIs and independent colleges face more difficulties in receiving student loans. Though the rural credit cooperative loan from an agency in the household's region and the two types of China Development Bank loans allow students from these two types of colleges to apply for loans in some provinces, they do not enjoyequal treatment with those from public HEIs. According to the 2007 survey mentioned previously, 114 of the 1652 sample students from private HEIs and independent colleges received student loans - accounting for only 7.7 per cent, which is much lower than the percentage of students from locally owned ordinary colleges and universities in the survey. 


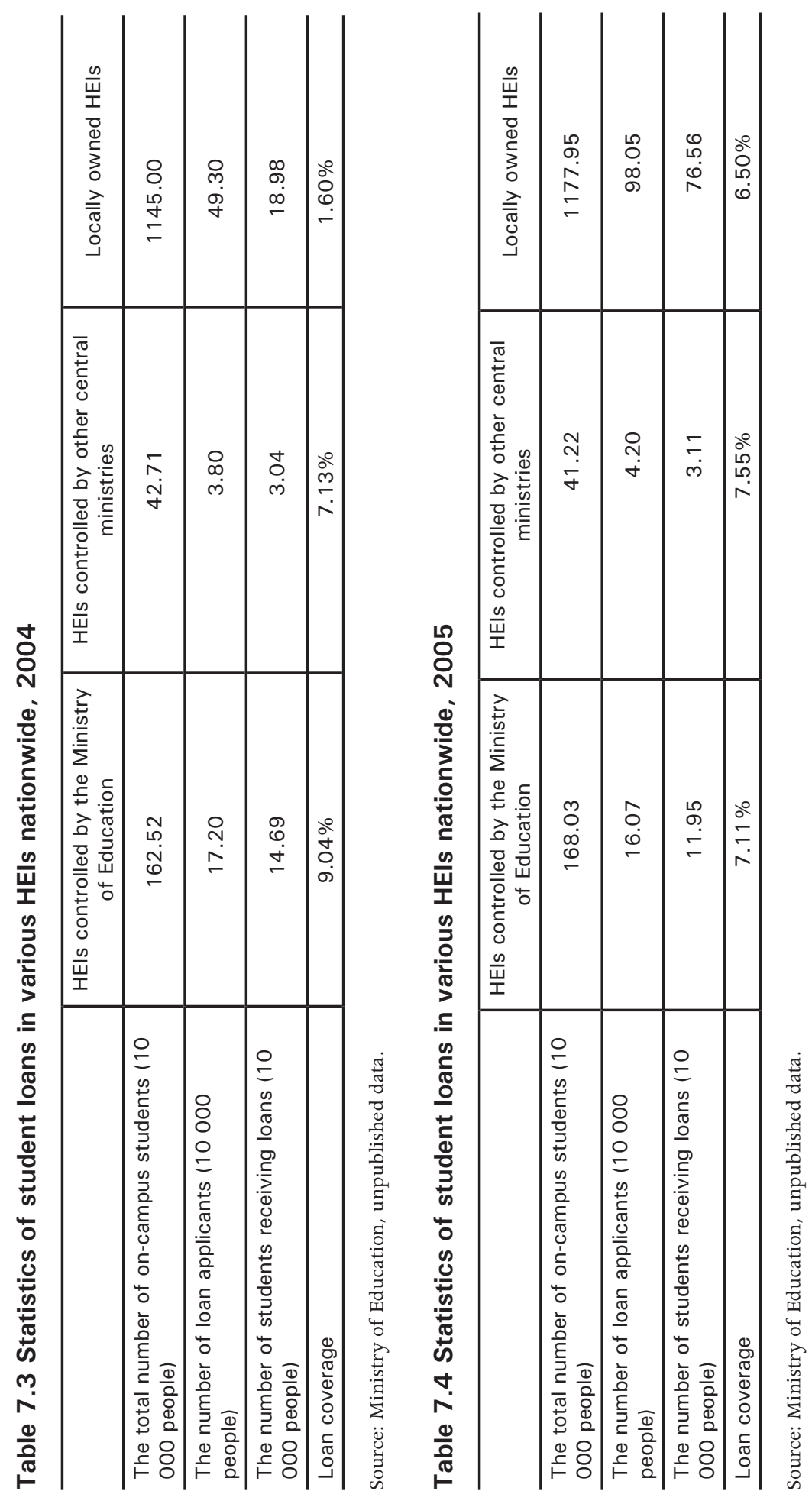


5. It is difficult to identify a student's family's financial conditions. All types of student loan programs offer loans with a government financial subsidy to needy students. When a loan application is examined, the student's family's economic situation will be identified. Since there is no strict and sound individual income tax declaration system in China and many taxpayers cannot meet the current standard of individual income tax deduction expenses, it is impossible to collect the information on all the students' families' economic situations.

6. There is no sound risk-sharing mechanism. As mentioned previously, instead of providing guarantees, the Chinese government shares and controls the risks of student loans by way of a risk compensation fund. This risk-sharing approach is not sound. Its main problems are as follows. HEIs bear half of the risk of the compensation fund. The number of students receiving loans will affect the amount of risk of the compensation fund the HEI bears. Unfairness could arise among different HEIs. More importantly, is it reasonable to require HEIs to bear the risk of the compensation fund? The specific meaning of the risk compensation fund is not the same for different types of loans. Under the commercial bank loan from an agency in the HEI's region and the rural credit cooperative loan from an agency in the household's region, the risk compensation fund is derived from income for the current period. No matter what the loan repayment is in the future, banks may receive a fixed amount of the risk compensation fund. This institutional arrangement will not solve the possible future risk-control problems. After getting the risk compensation fund, financial institutions will bear all the losses arising from loan defaults in the future. The financial institutions' worries about the future uncertainties have not been completely resolved. Under the China Development Bank loan from an agency in the HEI's and the household's regions, the risk compensation fund is not the bank's income for the current period. The final settlement depends on the collection performance. There is a loss-sharing system that defines that the China Development Bank, HEIs and provincial student assistance centres (or the China Development Bank and county-level government) share the loss together when the loan default amount is bigger than the risk compensation fund. This institutional arrangement defines the control and sharing mechanism of the future uncertain risks and there is also an incentive mechanism. There are, however, also problems in this system. With regard to incentives, the motivation chain is too long. The final settlement is after the expired repaymentdate. During this period, there could be many changes in personnel of the various agencies. There are no efficient indicators to give them day-to-day, real-time incentives. The reason is not strong enough for HEIs and county-level governments to bear the losses. As with bearing the risk compensation fund mentioned above, it is risky to require colleges and universities to share the loss. That the losses 
of loan defaults are borne by the county-level governments is not sufficient since students work in all parts of the country after graduation.

7. There are disadvantages with the repayment options. The repayment period for all types of student loans is six years, except for the China Development Bank loan from an agency in the household's region (its repayment period is 10 years for undergraduates). The repayment period of six years seems too short whether in comparison with international student loans or in consideration of the repayment burden of Chinese student loans. None of the four patterns takes into consideration all the exceptions when designing the repayment period, such as unemployment, low income, major diseases, emergencies, and so on. Regarding the forgiveness of student loans, the current policies of some provinces support only the student borrowers from the locally owned HEIs who work in designated areas of the same province, but do not support the above-mentioned students who work in poor areas of other provinces. Therefore, the issue of forgiveness will be considered from the central government's point of view. In addition, there is an extension system for postgraduates only for the commercial bank loan from an agency in the HEI's region and the China Development Bank loan from an agency in the HEI's region. Improvements to the other loan types should be made in a timely manner. The interest subsidy in loan-repayment extension is a very complicated issue. Local governments are reluctant to continue to subsidise the loan interest for locally owned HEI graduates who pursue their Master's degrees in other provinces. Like the forgiveness mentioned above, this issue will also be considered from the central government's point of view.

8. The coexistence and competition of the US Federal Family Education Loan (FFEL) and Federal Direct Loan (DL) give us positive inspiration (Galloway and Wilson 2005). Since none of the Chinese student loan patterns has obvious advantages, the strategy of coexistence and competition of various loan types should be adopted. The disadvantages mentioned above exist in basically all the student loan types. At present, the commercial bank loan from an agency in the HEI's region is applied across the country with regard to the policy coverage. But in some areas this pattern has stopped or has not been carried out at all. A rural credit cooperative loan from an agency in the household's region, the China Development Bank loan from an agency in the HEI's region and the China Development Bank loan from an agency in the household's region are offered in some areas.The feasible option for the future is to allow the coexistence and competition of a variety of student loan types, rather than choosing a single type, so as to find the most suitable type for each place through practice. This might offer friendly conditions for the formation of more mature patterns of student loans. 


\section{References}

Galloway, F. and Wilson, H. 2005, Reframing the Student Loan Costing Debate: The benefits of competition, Educational Policy Institute, Washington, DC, viewed 10 September 2008, <http://www.educationalpolicy.org/pdf/ loandebate.pdf>

Ministry of Education 2008, Brief Information on National Education Expenditure Statistics, Department of Finance Affairs, Ministry of Education, Beijing.

Yingquan, S. n.d., Rough estimation on the family income and educational cost of students of secondary vocational schools, vocational colleges and locally owned regular undergraduate colleges and universities, Unpublished draft ms. 
